\title{
Fokus narasi kekerasan seksual pada portal berita daring selama pandemi COVID-19
}

\author{
Nindi Aristi ${ }^{1}$, Preciosa Alnashava Janitra ${ }^{2}$, Puji Prihandini ${ }^{3}$ \\ 1,2, 3 Universitas Padjadjaran, Bandung, Indonesia
}

\begin{abstract}
ABSTRAK
Pemberlakuan kebijakan Pembatasan Sosial Berskala Besar (PSBB) selama masa pandemi COVID-19 yang menciptakan tekanan ekonomi serta dibarengi keterbatasan ruang gerak sosial individu berimplikasi terhadap peningkatan jumlah kasus kekerasan seksual di Indonesia. Pemberitaan terkait isu kekerasan seksual dinilai masih belum menjadi perhatian media kecuali jika kasus tersebut menyangkut figur publik. Penelitian ini bertujuan untuk mencermati kecenderungan pemberitaan di laman portal berita daring yang dengan asumsi akan memberi porsi lebih sejalan dengan bertambahnya kasus kekerasan seksual selama PSBB. Metode penelitian menggunakan metode analisis framing dengan cara menganalisis pemberitaan kasus kekerasan seksual pada laman portal Okezone.com dan Kompas.com selama periode bulan April - Oktober 2020 dengan menggunakan teori Framing. Hasil penelitian menunjukkan bahwa dalam pengidentifikasian masalah kasus kekerasan seksual yang terjadi dan menimpa kaum perempuan sebagai korban selama pemberlakuan PSBB masih meneguhkan budaya patriarki. Identifikasi sumber masalah pada laman portal berita Kompas.com telah berupaya untuk meliput dari dua sudut pandang (both sides of the story) dibandingkan Okezone.com walau fokus berita masih menguraikan latar belakang korban; moral judgement dikategorikan: kekerasan seksual terjadi di luar kontrol pelaku, patriarki sebagai ideologi yang melegitimasi kekerasan terhadap perempuan, kekerasan terhadap perempuan dapat menimbulkan berbagai dampak bagi korbannya, belum disahkannya RUU Penghapusan Kekerasan Seksual sebagai bentuk ketidakperhatian dan berdampak terhadap perempuan korban kekerasan seksual; serta rekomendasi solusi yang dibingkai oleh media masih condong penyelesaian masalah yang menyalahkan korban kekerasan, bukan pada antisipasi atau rekomendasi hukuman bagi pelaku. Dengan demikian fokus narasi pemberitaan tentang kasus kekerasan seksual masih jauh dari keberpihakan terhadap korban dan penegakan hukum yang adil.
\end{abstract}

Kata-kata Kunci: kekerasan seksual; portal berita; COVID-19; naratif; analisis framing

\section{Focus of sexual violence narrative in the online news coverage during the COVID-19}

\section{ABSTRACT}

The implementation of large-scale social restriction policies (PSBB) during the COVID-19 pandemic that creates economic pressures and accompanied by limited individual social mobility has implications for the increasing number of cases of sexual violence in Indonesia. News coverage regarding sexual violence issue is still not draw media attention unless the case concerns public figures. This study aims to look at the trend on online news portal that assume it will give more portion to sexual violence news in line with the increase in cases of sexual violence during the social restriction. The research uses framing analysis method by analyzing the news of sexual violence cases on Okezone.com and Kompas.com during the period of April-October 2020 using framing theory. The results shows that the identification of the problems can be seen the incidents and issues of sexual violence that occurred to the victims during the implementation of the of social restriction are still reinforces patriarchy culture; the define causes on the Kompas.com news portal has attempted to cover both sides of the story compared to Okezone.com even though the focus of the news still set on victim oriented; moral judgments are categorized as: sexual violence occurs outside control of the perpetrators; patriarchy as an ideology that legitimizes violence against women; violence against women can have various impacts on its victims; the fact that sexual violence eradication bill has not been ratified constitutionally can be seen as a form of indifference which will affect sexual violence victims; the recommendations for solutions framed by the media tend to blame the victim, instead of anticipation or punishment recommendation for the perpetrators. Therefore, the direction of the narrative of the news about sexual violence cases is still far from impartiality towards victims and fair law enforcement.

Keywords: sexual violence; news channel; COVID-19; narrative; framing analysisc

Korespondensi: Dr. Nindi Aristi, M.Comn. Universitas Padjadjaran. Jl. Raya Bandung Sumedang KM.21, Hegarmanah, Kec. Jatinangor, Sumedang, Jawa Barat. 45363.Email: nindi@unpad.ac.id 


\section{PENDAHULUAN}

Di seluruh negara penanganan COVID-19 menjadi hal prioritas untuk menjamin kehidupan dan kesejahteraan warga negaranya, tidak terkecuali pula yang dilakukan Pemerintah Indonesia. Beragam paket bantuan ekonomi diluncurkan dengan mempertimbangkan berbagai alasan penyelamatan keberlangsungan hidup masyarakat luas yang disebut dengan istilah program jaring pengaman sosial. Terdapat tujuh bantuan yang dikucurkan Pemerintah Indonesia yakni: bantuan sembako, bantuan sosial tunai, BLT dana desa, listrik gratis, kartu prakerja, subsidi gaji karyawan, dan BLT usaha mikro (Ihsanudin, 2020).

Program bantuan Pemerintah Indonesia kepada masyarakat tersebut memang sangat dibutuhkan untuk mengantisipasi angka inflasi dan tekanan ekonomi yang menghadang selama masa pandemi COVID-19. Meskipun demikian, urusan keselamatan masyarakat tidak akan utuh jika hanya memberikan jaminan dari aspek ekonomi saja, ada hal yang tampaknya luput dari perhatian Pemerintah yakni aspek jaminan rasa aman bagi setiap masyarakat Indonesia.

Menyoroti jaminan rasa aman bagi setiap masyarakat Indonesia khususnya kepada kelompok rentan yakni perempuan dan anak dapat dilihat dari data kasus kekerasan seksual. Selama sembilan tahun terakhir dalam kurun waktu tahun 2011 hingga tahun 2019 terdapat 46.698 kasus kekerasan seksual berdasarkan data Komisi Nasional (Komnas) Perempuan dengan rincian 23.021 kasus kekerasan seksual yang terjadi di ranah publik, pelecehan seksual 2.861 kasus, dan kejahatan melalui Internet sebanyak 91 kasus (Sulistiyono, 2020)

Lebih lanjut, kasus kekerasan seksual pun bergerak ke angka yang lebih meningkat selama masa pandemi COVID-19, berdasarkan data Sistem Informasi Online Perlindungan Perempuan dan Anak (Simfoni PPA) yang dipublikasi Kementerian Perlindungan Perempuan dan Anak periode bulan Januari - Juli 2020 terdapat 1.848 kasus kekerasan seksual terhadap anak (Kemen PPA, 2020). Situasi ini menunjukkan bahwa ada bahaya lain yang dialami perempuan selain bahaya tertular virus COVID-19.

Peningkatankasus kekerasan seksual selama masa pandemi COVID-19 dimungkinkan terjadi sebagai implikasi beberapa faktor penyebab antara lain: meningkatnya pemutusan hubungan kerja (PHK) di berbagai industri, bertambahnya angka pengangguran, menurunnya pendapatan personal, bertambahnya beragam kebutuhan keluarga, dan pemberlakuan kebijakan Pembatasan Sosial Berskala Besar (PSBB). Faktor-faktor tersebut ditambah dengan kebijakan PSBB yang diterapkan di beberapa wilayah Indonesia menyebabkan terbatasnya interaksi sosial antar manusia sehingga mengakibatkan kebosanan, depresi, putus asa dan rasa amarah semakin meningkat di level individu. Akibatnya pelampiasan rasa amarah cenderung dihempaskan kepada orang-orang yang berada di sekitar yang biasanya termasuk ke dalam kelompok rentan yakni perempuan.

Salah satu kajian terkait kekerasan domestik di Amerika selama periode awal pandemi COVID-19 mengungkapkan pemberlakuan kebijakan Pemerintah Amerika Serikat agar masyarakat beraktivitas di rumah (stay at home) membuka peluang meningkatnya ancaman kekerasan domestik. Istilah kekerasan domestik kerap digunakan pada kekerasan yang terjadi di antara hubungan pasangan yang mencakup kekerasan psikis, kekerasan fisik, dan kekerasan seksual. Situasi yang dikhawatirkan berbagai lembaga advokasi dan aktivis di Amerika Serikat adalah situasi yang mengharuskan isolasi di rumah menempatkan korban kekerasan domestik harus tetap serumah dengan pelaku kekerasan selama pandemi COVID-19. Keadaan ini dapat menimbulkan tekanan bagi pihak korban kekerasan. Jika korban kekerasan tetap tinggal bersama pelaku maka beresiko melanggengkan kekerasan dan bahkan meningkatkan tindak kekerasan selanjutnya. Jika korban kekerasan berpeluang pergi menjauh dari pelaku, mereka beresiko terpapar COVID-19 yang mematikan (Kofman \& Garfin, 2020)

Situasi ini sejalan dengan data kasus kekerasan seksual selama pandemi COVID-19 di wilayah Asia. Di India selama periode bulan Maret hingga Mei 2020 tercatat 1.477 kasus kekerasan domestik yang secara formal dilaporkan para korban (yakni perempuan) kepada institusi penegakan hukum. Angka ini melonjak tajam jika dibandingkan dengan angka kekerasan domestik di India selama kurun 10 tahun ke belakang (Radhakrishnan et al., 2020). Berdasarkan laporan UN Women terjadi peningkatan laporan tindak kekerasan sebesar 
30 persen di Singapura sejak pemberlakuan lockdown nasional (UN Women, 2020)

Pentingnya sinergitas dalam penanganan masalah kekerasan seksual di Indonesia serta koordinasi dari berbagai pihak, baik pemerintah, lembaga masyarakat, hingga media agar dapat bersama-sama memberikan kontribusi informasi, edukasi, serta advokasi secara nyata dan solutif. Pada artikel ini, peran media menjadi sorotan utama dengan alasan posisi sentral dan berkuasa yang masih dimilikinya sejak era tahun 1940an hingga kini dalam kehidupan masyarakat luas. Format media sudah mengalami perubahan dari media cetak hingga media daring saat ini.

Pembingkaian media melingkupi pemilihan berbagai elemen realitas yang dianggap bernilai berita, dan mengarahkan khalayak menuju aspek-aspek dan interpretasi tertentu (Shaw \& Giles, 2009). Pembingkaian media dapat diinterpretasikan dengan merujuk kepada pemahaman framing theory yang menyatakan bahwa pemberitaan media bersifat selektif dalam berbagai topik dengan artian subjektif dan mengadopsi perspektif episodik atau tematik. Perspektif episodik berfokus pada studi kasus dengan perhatian diarahkan pada individu dalam penanganan masalah sosial (Johnston et al., 2015)

Dalam konteks global, pemberitaan media tentang kekerasan seksual telah mengalami momentum perubahan berarti selama beberapa dekade terakhir, pertengahan tahun 1980an terjadi peningkatan liputan pemberitaan media ke arah pelecehan seksual terhadap anak. Periode selanjutnya pada tahun 2017 perhatian media mengarah kepada gerakan sosial \#MeToo (Rotenberg \& Cotter, 2018). Berlanjut ke periode berikutnya, penelitian-penelitian di beberapa negara mencatat perkembangan terkait kualitas liputan media terhadap korban kekerasan seksual seperti menurunnya liputan media yang cenderung menyudutkan atau bahkan menyalahkan korban kekerasan seksual (Morrison et al., 2021).

Menyoroti perubahan liputan pemberitaan media terkait kekerasan seksual di negaranegara lain di atas, menjadi pemantik untuk melihat liputan pemberitaan media dan narasi yang dikonstruksikan media terkait kasus kekerasan seksual khususnya pada masa pandemi COVID-19.

Dunia sosial pada dasarnya memiliki keterkaitan dengan media (Couldry \& Hepp, 2016). Hal tersebut sejalan dengan pemahaman bahwa media memiliki kemampuan untuk mengonstruksi realitas sosial, misalnya dalam konteks kekerasan seksual. Konstruksi realitas yang dilakukan oleh media tidak hanya melibatkan pemilihan isu atau peristiwa tertentu, tetapi juga bagaimana isu tersebut diinterpretasikan. Media dalam hal ini memilih berbagai isu dan dapat menginterpretasikannya berdasarkan perspektif tertentu (Yan, 2020). Dengan demikian, meskipun pemberitaan di media menampilkan fakta terkait kekerasan seksual, tetapi media berperan dalam menyajikan kembali fakta tersebut dengan memberi perhatian khusus pada aspek-aspek yang dianggap penting. Gagasan ini juga menjawab pertanyaan klasik yang kerap diajukan terhadap media massa terkait objektivitas realitas yang disajikan oleh media (Shoemaker \& Reese, 2013).

Uraian mengenai kapabilitas media dalam mengkonstruksi realitas pada intinya menunjukkan bahwa media tidak dapat menunjukkan realitas secara utuh atau secara benar-benar objektif. Hal ini bertentangan dengan anggapan bahwa media hanya berfungsi sebagai cerminan realitas atau 'jendela ajaib' yang dapat membantu khalayak melihat realitas yang seutuhnya (Potter, 2016). Padahal, media bukanlah 'jendela ajaib', bahkan sebenarnya media dapat mendistorsi realitas. Hal ini karena berbagai bias yang dimiliki oleh media tersebut. Misalnya dalam representasi identitas, sebuah penelitian menunjukkan bagaimana 11 peliputan berita terkait terorisme di Amerika Serikat setelah peristiwa 9/11 didominasi oleh terorisme internasional, khususnya yang diasosiasikan dengan Muslim/Arab/Islam (Powell, 2011). Sedangkan terorisme domestik hanya dianggap sebagai ancaman minor. Sementara itu, dalam konteks kekerasan terhadap perempuan, Benedict pada 1993 telah mengidentifikasi beberapa mitos pemerkosaan yang seringkali dilanggengkan oleh berita di media. Adapun mitos-mitos tersebut di antaranya yaitu bahwa pemerkosaan sama dengan hubungan seksual, pelakunya termotivasi oleh nafsu, pelaku adalah orang cabul atau pengidap gangguan kejiwaan, serta bahwa perempuan memprovokasi tindak pemerkosaan (Geertsema Sligh, 2018). Peran media dalam menghadirkan kembali realitas sekaligus membentuknya tidak terlepas dari 
proses kerja dalam industri media itu sendiri. Karena itu untuk memahami analisis framing terhadap suatu pemberitaan, pemahaman terhadap kerja media dalam memproduksi suatu berita juga menjadi hal yang krusial. Pengaruh kerja media terhadap produk media ini salah satunya dapat dijelaskan melalui model hierarchy of influences atau hierarchical model yang diperkenalkan oleh Pamela Shoemaker dan Stephen D. Reese pada tahun 2013.

Menurut Shoemaker dan Reese konten media dipengaruhi oleh lima level faktor, yaitu level individu, praktik rutin, organisasi media, institusi sosial, dan sistem sosial (Shoemaker \& Reese, 2013). Level individu dapat dipahami sebagai karakteristik komunikator, dalam hal ini para pekerja atau praktisi media. Level praktik rutin mencakup struktur, pola-pola, atau rutinitas tempat individu bekerja. Meski tampak mirip, namun level organisasi sebenarnya berbeda dengan rutinitas. Level ini menjelaskan pengaruh entitas terorganisasi yang lebih besar sebagai tempat individu bekerja. Beberapa elemen yang terdapat pada level organisasi yaitu peran terkait pekerjaan, kebijakan organisasi, dan struktur dalam perusahaan. Level ketiga, institusi sosial, menjelaskan tentang pengaruh yang ditimbulkan oleh media trans-organisasional, yakni bagaimana organisasi-organisasi media menjadi bagian dari hubungan terstruktur yang lebih besar. Level terakhir, yaitu sistem sosial, mencakup pengaruh sistem secara keseluruhan terhadap konten media. Pada level ini kekuatankekuatan ideologis memiliki peranan yang sangat penting. Misalnya bila dikaitkan dengan pemberitaan tentang kekerasan seksual, maka ideologi patriarki di Indonesia yang cenderung menempatkan perempuan pada posisi subordinat akan berperan dalam menentukan cara media merepresentasikan perempuan pada berita-berita tersebut.

Oleh karena itu, pembingkaian media terhadap suatu isu juga tidak dapat dilepaskan dari ideologi media. Ideologi ini dikonstruksi dan didistribusikan utamanya melalui framing, atau cara informasi tersebut dikelola dan dipresentasikan (Powell, 2011). Pemikiran ini juga meneguhkan pernyataan bahwa media massa adalah kendaraan bagi ideologi. Ideologi media inilah yang juga hadir dalam konten pemberitaan walaupun seperti yang telah disinggung sebelumnya, ideologi dominan di masyarakat juga sangat berperan. Sebagai contoh, meski Indonesia masih didominasi oleh ideologi patriarki yang tercermin dalam berbagai konten media arus utama, tetapi media alternatif seperti media daring Magdalene. co telah berupaya menghadirkan konten yang lebih sensitif gender. Penelitian menunjukkan bahwa Magdalene.co menawarkan nilai-nilai dan perspektif baru terkait perempuan (Maryani \& Adiprasetio, 2017). Penelitian lainnya yang dilakukan terhadap media Tirto.id juga menunjukkan bahwa media dapat memberikan edukasi kepada masyarakat terkait perjuangan untuk menghentikan kekerasan seksual terhadap perempuan (Rahayu \& Agustin, 2019).

Tucker menyatakan bahwa ideologi dan kepentingan media adalah dua hal yang beririsan. Kepentingan yang dimiliki media sangat berperan dalam menentukan pembingkaian atas isu yang ditampilkannya. Di antaranya yaitu kepentingan ekonomi dan politik yang dimiliki oleh produsen media. Berkaca pada hal tersebut maka teori framing sangat tepat untuk analisis kebudayaan secara kritis karena tertarik pada kekuasaan yang dimiliki oleh produsen media yang mengkonstruksi bingkai (frame) (Pennington \& Birthisel, 2015).

Salah satu penelitian yang mengkaji tentang pemberitaan surat kabar yang meliput kekerasan domestik terhadap perempuan selama periode lockdown COVID-19 di Nigeria adalah riset yang dilakukan oleh Ekweonu. Riset yang menggunakan metode analisis isi terhadap tiga surat kabar terbesar yakni: Daily Sun, Vanguard, dan Guardian dilakukan selama bulan Maret hingga Juni 2020. Hasil dari 300 publikasi berita di tiga surat kabar tersebut menunjukkan bahwa pada surat kabar tersebut tidak memberikan liputan berita yang memadai terkait kekerasan domestik terhadap perempuan. Selain itu pun, tidak ada tindak lanjut pemberitaan tentang kasus domestik dan hanya diliput secara terbatas. Ekweonu menyimpulkan bahwa surat kabar tersebut tidak berhasil meliput kekerasan domestik selama periode riset yang telah ditentukan (Ekweonu, 2020).

Lebih lanjut, berdasarkan data pemberitaan diketahui sumber intervensi paling dominan dalam kekerasan domestik terhadap perempuan dilakukan oleh lembaga swadaya masyarakat. Hal ini menyiratkan bahwa Pemerintah Nigeria hanya memeroleh informasi minim dalam penanganan kekerasan domestik 
karena budaya yang berlaku melarang perempuan mengungkapkan tindak kekerasan yang dilakukan pasangannya. Penelitian ini merekomendasikan media seharusnya menjalankan fungsi tanggung jawab sosial kepada masyarakat untuk mengekspos efek kekerasan domestik terhadap perempuan yang masih marak terjadi di Nigeria. Ekweonu mendorong agar media massa menindaklanjuti berita-berita tentang kekerasan domestik terhadap perempuan untuk memberikan analisis tematik yang dapat membantu masyarakat Nigeria mengadopsi perubahan sikap dalam menekan angka kekerasan terhadap perempuan (Ekweonu, 2020).

Pemberitaan mengenai isu kekerasan seksual di Indonesia telah menjadi fokus dalam berbagai kajian komunikasi dan media sebelum pandemi COVID-19. Salah satu penelitian terkait berita perkosaan memperlihatkan bahwa media mengonstruksikan seksualitas perempuan sebagai sesuatu yang dikendalikan laki-laki (Susilo \& Haezer, 2017). Penelitian lainnya terhadap Okezone.com di tahun 2019 mengungkapkan bahwa media tersebut cenderung menempatkan perempuan korban perkosaan sebagai pihak yang bersalah. Berdasarkan bahasa yang dipilih, media seolah memposisikan perempuan sebagai pihak yang turut berkontribusi atas terjadinya tindak perkosaan (Pada et al., 2020). Meskipun telah terdapat berbagai kajian tentang pemberitaan kekerasan seksual di Indonesia, tetapi kajian serupa yang spesifik membahas kekerasan seksual pada masa pandemi masih terhitung minim.

Masih minimnya pembahasan mengenai media yang mengangkat isu kekerasan seksual selama pandemi COVID-19 dan pemberlakuan kebijakan Pembatasan Sosial Berskala Besar (PSBB) di Indonesia mengilhami penulisan artikel ini. Fokus masalah yang penulis kaji dalam tulisan ini adalah bagaimana media daring menarasikan pemberitaan kasus kekerasan seksual yang terjadi selama pemberlakuan kebijakan Pembatasan Sosial Berskala Besar (PSBB) di Indonesia?

Alasan peneliti memilih pemberitaan di portal berita daring untuk diteliti adalah terkait dengan fenomena digitalisasi dalam beragam industri, termasuk industri media cetak. Digitalisasi dalam media cetak ini, disebabkan salah satunya adalah penurunan oplah media cetak. Hal ini dapat terlihat dari data yang dirangkum oleh tirto id bahwa selama 8 tahun terakhir oplah media cetak mengalami perlambatan dan penurunan (Zuhra, 2017). Dengan penurunan oplah tersebut, membuat pelaku industri media cetak harus bertransformasi ke ranah digital. Format informasi dalam bentuk digital ini mengurangi beban biaya cetak dan distribusi yang membuat lebih menguntungkan (Rumata, 2017). Digitalisasi media cetak ini juga sejalan dengan tren pembaca media daring yang cenderung selalu naik tiap tahunnya (Kurnia \& Assidiq, 2018).

Berdasarkan pemaparan tersebut maka tujuan dari penelitian ini adalah secara umum untuk mengetahui bagaimana realitas mengenai kekerasan seksual selama masa pandemi COVID-19 ini dibingkai oleh media. Secara lebih spesifik, penulis ingin mengetahui a) bagaimana identifikasi masalah (problem identification) mengenai pemberitaan narasi kekerasan seksual selama pandemic COVID-19, b) bagaimana identifikasi penyebab masalah (causal interpretation) yakni siapa yang dianggap penyebab masalah dalam pembingkaian peristiwa kekerasan seksual dalam portal berita daring selama COVID-19, c) bagaimana evaluasi moral (moral evaluation) yakni penilaian atas penyebab masalah dari peristiwa kekerasan seksual dalam portal berita daring selama COVID-19, dan d) bagaimana saran penanggulangan masalah (treatment recommendation), dalam kasus kekerasan seksual dalam pemberitaan di media daring selama COVID-19.

\section{METODE PENELITIAN}

Metode penelitian yang dapat digunakan untuk membahas isu pembingkaian media dalam kacamata media massa adalah metode penelitian kuantitatif dan kualitatif. Beberapa studi menggunakan analisis isi kuantitatif atau analisis bingkai dengan bantuan komputer (seperti pemetaan bingkai), sementara studi lain lebih menyukai pendekatan kualitatif interpretatif berbasis teks (Linström \& Marais, 2012).

Metode penelitian yang digunakan dalam penelitian adalah metode penelitian kualitatif. Penulis menggunakan metode penelitian kualitatif disesuaikan dengan maksud dan 
tujuan penelitian, yakni menggambarkan realitas pelecehan seksual dalam kacamata portal media daring di Indonesia. Peneliti tidak bermaksud untuk mengukur efek pemberitaan, seperti pada penelitian pada metode kuantitatif. Namun sebaliknya, peneliti ingin mengetahui bagaimana media menafsirkan sebuah isu atau peristiwa. Menurut Linstrom dan Marais, metode kualitatif sangat berharga ketika kita tidak ingin menghitung atau mengukur fenomena tetapi untuk memahami karakter pengalaman, terutama bagaimana orang memandang dan memahami pengalaman komunikasi mereka. Ini melibatkan penafsiran makna dan dimensi komunikasi lain yang tidak dapat diamati (Linström \& Marais, 2012).

Penelitian mengenai narasi kekerasan seksual pada portal berita daring di Indonesia selama masa pandemik COVID-19 ini menggunakan jenis penelitian framing sebagai pisau analisis penelitian. Secara konseptual, framing bisa dikatakan memiliki dua fondasi yang luas, yakni yang pertama merupakan perspektif sosiologis dimana para tokohnya adalah Entman (1991), Gamson \& Modigliani (1987), Gitlin (1980) dan Goffman (1974). Kedua, masuk ke dalam perspektif psikologis, para ahli dari perspektif ini antara lain ialah Domke, Shah, \& Wackman (1998), Iyengar (1991), dan Kahneman \& Tversky (1984). Penelitian framing yang tumbuh dari landasan sosiologis menurut Chong \& Druckman mengacu pada "bingkai dalam komunikasi" dan secara umum, penelitian ini cenderung berfokus pada "'kata, gambar, frasa, dan gaya presentasi" yang digunakan untuk menyusun berita dan prosesnya yang membentuk konstruksi ini (Borah, 2011).

Goffman adalah salah satu ilmuwan pertama yang mengembangkan konsep framing. Goffman menyebut bingkai sebagai 'skema interpretasi, 'sebuah kerangka kerja yang membantu dalam membuat rangkaian peristiwa yang tidak berarti menjadi sesuatu yang bermakna Gitlin mendefinisikan frame sebagai perangkat yang memfasilitasi bagaimana jurnalis berorganisasi sejumlah besar informasi dan mengemasnya secara efektif untuk audiens mereka. Gitlin melihat bingkai sebagai pola kognisi, interpretasi, dan presentasi yang persisten, seleksi, penekanan, dan pengecualian (Borah, 2011).

Sarjana lain yang juga memberikan pemikiran yang cukup menyita perhatian adalah Entman, berdasarkan pandanganya framing melibatkan seleksi dan arti-penting. Membingkai adalah memilih beberapa aspek dari realitas yang dirasakan dan membuat mereka lebih menonjol dalam teks komunikasi yang sedemikian rupa. Pembingkaian bisa saja konotasi yang signifikan karena bingkai menyoroti beberapa aspek realitas sambil mengecualikan elemen lain, yang mungkin mengarahkan individu untuk menafsirkan masalah secara berbeda (Borah, 2011).

Pada penelitian ini, penulis menggunakan analisis framing yang dikemukakan oleh Sosiolog dari Amerika yakni Robert M Entman. Menurut Entman, framing telah mengatur porsi literatur yang semakin meningkat tentang representasi media. Representasi dalam sebuah realitas selalu parsial, selalu membutuhkan pemilihan aspek untuk mewakili keseluruhan (jika tidak, menurut Entman, kita akan berbicara tentang presentasi, bukan representasi) (Entman, 2015). Media massa melakukan pembingkaian realitas ke dalam sebuah bentuk karya jurnalistik salah satunya adalah berita. Menurut Entman, pembingkaian merupakan sebuah proses pemilihan, penyorotan, dan penindasan. Pembingkaian merupakan sarana yang digunakan sebagian besar representasi media. Pembingkaian dapat didefinisikan sebagai memilih aspek-aspek dari realitas yang dirasakan dan membuatnya lebih menonjol dalam teks yang berkomunikasi, dengan demikian mempromosikan definisi masalah tertentu, interpretasi kausal, evaluasi moral, $\mathrm{dan} /$ atau rekomendasi pengobatan ( Entman, 2015).

Entman menuliskan bahwa secara esensial, framing terdiri dari seleksi dan ciri khas. Framing berarti melakukan seleksi dari beberapa aspek realitas yang dirasakan dan membuat mereka lebih menonjol dalam teks komunikasi, sedemikian rupa untuk mempromosikan beberapa definisi masalah, penafsiran kausal, evaluasi moral dan atau rekomendasi perlakuan dari sebuah isu/peristiwa/realitas (Entman, 1993). Secara garis besar pemikiran Entman terkait framing terdiri dari (Entman, 1993): Mendefinisikan masalah (Define Problems), pada tahap ini merupakan langkah awal dimana tahap framing diawali dengan menentukan agen kausal yang dilakukan dengan perhitungan biaya dan keuntungan, biasanya diukur dengan 
nilai budaya yang umumnya dipegang oleh masyarakat. Melakukan diagnosis terhadap penyebab masalah (Diagnose Causes), Pada tahap ini peneliti melakukan identifikasi latar belakang yang membentuk sebuah masalah. Membuat penilaian moral (Make Moral Judgement), Melakukan evaluasi agen kausal dan efeknya. Menawarkan solusi (Suggest Remedies). Menawarkan dan menjustifikasi perlakuan terhadap permasalahan.

Objek penelitian ini adalah berita-berita mengenai pelecehan seksual yang dimuat oleh portal berita daring Okezone.com dan Kompas. com selama periode April-awal Oktober 2020. Alasan pemilihan dua portal berita daring tersebut karena berdasarkan data yang diperoleh dari situs Alexa.com yang bergerak di bidang analisis website dan pengembangan search engine optimization (SEO) bahwa Okezone.com dan Kompas.com masuk ke dalam rangking 5 besar sebagai situs yang paling banyak dikunjungi di Indonesia.

Penelitian mengenai analisis framing peristiwa kekerasan seksual selama masa pandemi COVID-19 ini dilakukan selama 7 bulan, yakni selama bulan April-Oktober 2020. Pengumpulan data dilakukan mulai dari bulan April hingga awal Oktober 2020, kemudian analisis data serta pembahasan terhadap hasil pengumpulan data dilakukan pada bulan Oktober 2020. Adapun lokasi penelitian ini dilakukan di Indonesia dengan menggunakan bantuan perangkat komputer dan jaringan Internet.

Penulis mengumpulkan berita mengenai kasus/peristiwa terkait kekerasan seksual yang terjadi di Indonesia selama bulan April - Oktober 2020. Berita tersebut dikumpulkan dari dua portal berita daring Indonesia yakni Kompas.com dan Okezone.com.

Pengumpulan data dilakukan dengan mengunjungi portal berita daring yang penulis teliti yakni Okezone.com dan Kompas.com, kemudian penulis mulai mencari berita-berita mengenai kekerasan seksual yang dimuat dalam dua situs tersebut dengan memasukkan kata kunci "kekerasan seksual" pada filter pencarian dalam masing-masing website. Dari hasil pengumpulan data selama 6 bulan tersebut, terdapat 32 berita mengenai kekerasan seksual selama masa pandemi COVID-19. Terdokumentasikan sebanyak 19 berita dari portal berita Okezone dan 13 berita dari portal
Tabel 1 Analisis Framing menurut Entman yang dimodifikasi penulis berdasarkan isu kekerasan seksual

\begin{tabular}{|c|c|c|}
\hline No & Tahapan & Deskripsi \\
\hline 1 & $\begin{array}{l}\text { Define Problems } \\
\text { (pendefinisian } \\
\text { masalah) }\end{array}$ & $\begin{array}{l}\text { Bagaimana suatu } \\
\text { peristiwa / isu } \\
\text { kekerasan seksual } \\
\text { dilihat oleh media? } \\
\text { Sebagai apa? Atau } \\
\text { sebagai masalah } \\
\text { apa? }\end{array}$ \\
\hline 2 & $\begin{array}{l}\text { Diagnose causes } \\
\text { (memperkirakan } \\
\text { masalah atau } \\
\text { sumber masalah) }\end{array}$ & $\begin{array}{l}\text { Peristiwa pelecehan } \\
\text { seksual t dilihat } \\
\text { disebabkan oleh } \\
\text { apa? Apa yang } \\
\text { dianggap sebagai } \\
\text { penyebab dari } \\
\text { kekerasan seksual? } \\
\text { Siapa (aktor) yang } \\
\text { dianggap sebagai } \\
\text { penyebab kekerasan } \\
\text { seksual? }\end{array}$ \\
\hline 3 & $\begin{array}{l}\text { Make moral } \\
\text { judgement } \\
\text { (membuat } \\
\text { keputusan moral) }\end{array}$ & $\begin{array}{l}\text { Nilai moral apa } \\
\text { yang disajikan } \\
\text { untuk menjelaskan } \\
\text { peristiwa kekerasan } \\
\text { seksual? nilai } \\
\text { moral apa yang } \\
\text { dipakai untuk } \\
\text { melegitimasi atau } \\
\text { mendelegitimasi } \\
\text { suatu tindakan? }\end{array}$ \\
\hline 4 & $\begin{array}{l}\text { Treatment } \\
\text { Recommendation } \\
\text { (menekankan } \\
\text { penyelesaian) }\end{array}$ & $\begin{array}{l}\text { Penyelesaian apa } \\
\text { yang ditawarkan } \\
\text { untuk mengatasi } \\
\text { masalah / isu } \\
\text { kekerasan seksual? } \\
\text { Jalan apa yang } \\
\text { ditawarkan dan } \\
\text { harus ditempuh } \\
\text { untuk mengatasi } \\
\text { masalah/isu } \\
\text { kekerasan seksual? }\end{array}$ \\
\hline
\end{tabular}

Sumber: Hasil Penelitian, 2020

berita daring Kompas.com.

Selain mengumpulkan data primer, penulis pun melakukan pengumpulan data sekunder yang bersumber dari beragam jurnal terakreditasi nasional maupun jurnal ter indeks 
Scopus untuk mendukung asumsi sebagai landasan teori dan fenomena kekerasan seksual dalam pemberitaan media.

Analisis data pada penelitian ini menggunakan Teknik analisis framing yang dikembangkan oleh Robert M. Entman pada 1993. Penulis menggunakan teknik analisis framing Robert M. Entman ini karena dapat membantu penulis untuk mendefinisikan masalah terkait pelecehan seksual selama masa pandemi COVID-19 dan juga dalam menginterpretasikan narasi pemberitaan kedua portal berita daring di Indonesia terkait kekerasan seksual selama masa pandemi COVID-19. Dalam pandangan Entman, framing dipandang sebagai penempatan informasi dalam konteks yang khas sehingga isu tertentu mendapat alokasi penempatan yang lebih besar daripada isu lainnya (Anggoro, 2014). Secara sederhana unit analisis data dalam penelitian ini dapat digambarkan dalam bentuk tabel 1 .

\section{HASIL DAN PEMBAHASAN}

Penggunaan metode framing telah banyak diadopsi dan diaplikasikan pada kajian tekstual, psikologis, serta sosial politik. Dalam hal ini metode framing penulis gunakan untuk mengkaji pemberitaan media daring berlandaskan perspektif komunikasi. Penekanan metode framing yang terletak pada penyediaan konteks informasi dipresentasikan dan diproses membuka kesempatan untuk mengadopsinya dalam berbagai spektrum fenomenakomunikasi.Pakarmediamemberikan perhatian bahwa pembingkaian berita dapat memformulasikan isu alternatif lainnya seperti bias dan objektivitas. Hackett menyatakan bahwa news framing bukanlah proses yang sepenuhnya disadari oleh jurnalis atau media namun merupakan hasil asumsi bawah sadar tentang masalah dunia sosial (Hackett, 1984).

Dalam memahami berita yang dipublikasikan oleh sebuah institusi media selain perlu mengeksplorasi proses media mengkonstruksikan "realita" yang disajikannya kepada audiens juga perlu untuk memahami ideologi media tersebut. Pawito menyatakan bahwa pada dasarnya ideologi media merupakan gagasan-gagasan atau nilai-nilai pokok yang diusung oleh media massa dan kemudian diterjemahkan ke dalam pesan-pesan yang disampaikan kepada khalayak (Pawito, 2014).

Hasil studi literatur menunjukkan adanya perbedaan antara ideologi media kedua portal media daring tersebut. Hal ini dapat terlihat dari bagaimana penyusunan pesan dan pemilihan diksi dalam pemberitaan mengenai topik gender yang disajikan dalam artikel di kedua portal media daring tersebut. Dalam konteks ideologi gender dan patriarki, Portal media daring Kompas.com menunjukkan kebebasan dan memberikan ruang bagi perempuan untuk berekspresi. Hal ini dapat terlihat dari penelitian yang dilakukan oleh Kamila dan Laksmi mengenai pemberitaan mengenai perempuan di Kompas.com. Hasilnya menunjukkan terdapat kontradiksi antara informasi mengenai perempuan dalam berita dengan konsep budaya patriarki dari keseluruhan berita yang diteliti. Kontradiksi yang dimaksud adalah kaum perempuan dapat menjadikan berita pada media online sebagai sumber inspirasi dalam mengembangkan dirinya untuk hidup dan berkarya sesuai keinginan tanpa adanya batasan dan larangan. Hal tersebut bertolak belakang dengan konsep budaya patriarki (Kamila \& Laksmi, 2018).

Berbeda dengan Kompas.com, portal media daring Okezone.com masih menonjolkan karakter patriarki yang masih cukup dominan, terutama dalam wacana kekerasan dan gender. Karakter patriarki menjadi alasan para pelaku kekerasan dalam menjalankan aksinya tersebut. Tidak sedikit juga kasus yang berlandaskan hubungan inses (sedarah kandung) yang juga menjadi alasan subjek kekerasan untuk mendapat keringanan atau pemakluman dari apa yang dilakukan (Pada et al., 2020). Adanya perbedaan ideologi antara kedua media ini mendasari peneliti untuk menjadikan Kompas. com dan Okezon.com sebagai objek penelitian.

Dari penelusuran penulis dengan menggunakan kata kunci "kekerasan seksual" di Okezone.com selama April - Oktober 2020 tercatat 19 berita, kemudian didefinisikan masalah dalam setiap pembingkaian berita pada tabel 2.

Berdasarkan data riset diketahui bahwa terdapat 12 pemberitaan dengan kata kunci "kasus kekerasan seksual" di Kompas.com. Berikut pemaparan pendefinisian masalah dalam pembingkaian Kompas.com pada tabel 3 .

Dari pemaparan pengidentifikasian masalah di atas dapat diketahui bahwa peristiwa 
Tabel 2 Pendefinisian Masalah dalam Isi Pemberitaan Kasus Kekerasan Seksual di Okezone.com periode April - Oktober 2020

\begin{tabular}{cl}
\hline Tanggal & \multicolumn{1}{c}{ Judul } \\
\hline 06-Sep-20 & $\begin{array}{l}\text { Kasus KDRT P21, Karen } \\
\text { Pooroe Tak Sabar Bertemu } \\
\text { Mantan Suami di Pengadilan }\end{array}$ \\
& Karen Pooroe Tak Sabar \\
06-Sep-20 & $\begin{array}{l}\text { Hadapi Mantan Suami di } \\
\text { Pengadilan }\end{array}$ \\
30-Aug-20 & $\begin{array}{l}\text { Perempuan Disebut Paling } \\
\text { Terbebani Akibat Pandemi } \\
\text { COVID-19, Ini Penyebabnya }\end{array}$
\end{tabular}

21-Aug-20 Megawati Wajibkan Calon Kepala Daerah Baca BukuBuku Ini

13-Aug-20 Hari Remaja Internasional, BKKBN Tingkatkan Program GenRe bersama Remaja Disabilitas

11-Aug-20 Pelaku saat Memperkosa Perempuan di Bintaro dalam Kondisi Mabuk

\section{1-Jul-20 BKKBN Beri Edukasi}

Kesehatan Reproduksi Anak Remaja di Era Pandemi

10-Jul-20 Hari Kependudukan Dunia; Dampak COVID-19 Terhadap KB, Kesehatan Ibu, Hingga Kekerasan Berbasis Gender

03-Jul-20 Viral Pria Pukuli Wanita Bertubi-tubi, Saksi Sebut Korban Menjerit Kesakitan

17-Jun-20 Polisi Bongkar Makam Gadis 16 Tahun yang Diperkosa Bergilir di Tangsel

11-Jun-20 Bagi Korban KDRT, WFH Itu Mengerikan
Pendefinisian Masalah dalam Isi Pemberitaan

(Define problems)

Isi berita mengetengahkan berkas kasus KDRT artis yang maju ke pengadilan. Visualisasi berita memuat 2 gambar artis tersebut dan 1 gambar mantan suaminya yang berperkara.

Isi berita menceritakan rasa senang artis yang berkas perkaranya lengkap dan segera disidangkan. Visualisasi berita memuat foto artis tersebut dengan fokus pose tertentu.

Dampak COVID-19 terhadap perempuan yang menambah beban ekonomi dan beban peran domestik. Visualisasi berita gambar tiga perempuan bermasker duduk di ruang tunggu.

Megawati menyarankan Calon Kepala Daerah membaca buku Sarinah yang mengungkap data KDRT terhadap perempuan. Visualiasasi berita gambar Megawati.

Penyandang disabilitas di Indonesia mengalami diskriminasi ganda, kekerasan berbasis gender, penganiayaan, dan marginalisasi. Visualisasi berita dokumentasi BKKN.

Kasus perkosaan yang menimpa AF disebabkan korban mengenakan pakaian minim yang membuat pelaku spontan memperkosa. Visualisasi berita ilustrasi seorang perempuan

Kegiatan webinar BKKN tentang peran perempuan dan masalah reproduksi saat COVID-19.

Visualisasi berita gambar kegiatan webinar.

Penurunan akses layanan kontrasepsi berdampak

pada unwanted pregnancy dan miss time

pregnancy. Visualisasi berita Kepala BKKBN.

Kejadian pemukulan laki-laki terhadap perempuan di Baubau, Sultra. Visualisasi berita ilustrasi orang menutup wajah.

Pembongkaran makam korban pemerkosaan guna mencari bukti persetubuhan yang dilakukan 9 pelaku. Visualisasi berita gambar keluarga korban.

KemenPPA mendorong lembaga UPTDPPA dan P2TP2A untuk aktif mendata kasus KDRT di wilayahnya. Visualisasi berita gambar kepalan tangan laki-laki dan sosok perempuan yang samar. 


\section{1-Jun-20 Kemen PPPA Minta Petugas \\ Pro Aktif Tangani Kasus KDRT}

11-Jun-20 Selama PSBB Laporan Kasus KDRT Turun

\section{1-Jun-20 Kemen PPPA Tingkatkan Layanan bagi Korban KDRT dengan Jemput Bola}

$\begin{array}{ll}\text { 20-May-20 } & \text { Perempuan Kian } \\ & \text { "Terperangkap" di Tengah } \\ & \text { Pembatasan Sosial } \\ & \text { COVID-19 }\end{array}$

11-May-20 Satu Keluarga di Sulsel Bunuh Anak Perempuan Diduga karena Berbuat Mesum

$\begin{array}{ll}\text { 01-May-20 } & \text { May Day, Pemerintah } \\ & \text { Diminta Beri Perhatian } \\ & \text { Khusus pada Pekerja } \\ & \text { Perempuan }\end{array}$

\begin{tabular}{|c|c|}
\hline 29-Apr-20 & $\begin{array}{l}\text { Kekerasan terhadap } \\
\text { Perempuan \& Anak } \\
\text { Meningkat Selama Wabah } \\
\text { Corona }\end{array}$ \\
\hline 21-Apr-20 & $\begin{array}{l}\text { Waspada, COVID-19 } \\
\text { Memicu Kekerasan Dalam } \\
\text { Rumah Tangga }\end{array}$ \\
\hline
\end{tabular}

KemenPPA mendorong agar UPTDPPA dan P2TP2A jemput bola kasus KDRT di wilayahnya. Visualisasi berita gambar tangan bertuliskan "stop hurting us!"

Penurunan laju pertambahan kasus KtP dan KDRT periode Januari - Juni 2020 mencerminkan hilangnya akses pelaporan kasus selama PSBB. Visualisasi berita gambar wajah perempuan ketakutan.

Pelayanan pelaporan kasus KDRT saat pandemi yang lebih pro aktif melalui relawan \#BERJARAK, UPTD PPA, dan P2TP2A. Visualisasi berita gambar kepalan tangan laki-laki dan sosok perempuan yang samar.

Kerentanan perempuan terhadap kekerasan terutama KDRT meningkat selama masa pandemi COVID-19 sebagai akibat relasi timpang laki-laki dan perempuan. Visualisasi berita gambar laki-laki yang hendak menampar perempuan.

Anak perempuan sebagai korban pembunuhan keluarganya sendiri akibat malu tentang kasus hubungan percintaan korban dengan sepupunya. Visualisasi berita ilustrasi sosok perempuan meninggal.

Komnas Perempuan mendorong pemerntah menyeduakan skema bantuan sosial khusus pekerja perempuan lintas sektor dalam jaring pengaman sosial. Visualisasi berita gambar buruh perempuan demo.

Peluncuran layanan Sejiwa bagi masyarakat untuk melaporkan kasus KDRT, eksploitasi, perlakuan salah, penelantaran baik secara online atau offline. Visualisasi berita ilustrasi anak-anak bermain.

Masa PSBB berpotensi menciptakan konflik dalam rumah tangga karena berimbas pada terbatasnya layanan korban untuk berlindung ke Rumah Singgah maupun Rumah Aman. Visualisasi berita ilustrasi laki-laki hendak menampar perempuan.

Sumber: Hasil Penelitian, 2020

dan isu kekerasan seksual yang terjadi dan menimpa mayoritas perempuan sebagai korban selama pemberlakuan PSBB masih diberitakan selayaknya kasus kriminalitas umum. Keberpihakan media yakni Okezone. com dan Kompas.com dalam memberitakan kasus kekerasan seksual dengan sudut pandang yang lebih humanis dan mendorong adanya keterlibatan pemerintah dan masyarakat belumlah tampak jelas.

Langkah selanjutnya dalam analisis framing Entman setelah pendefinisian masalah adalah memperkirakan masalah atau mengidentifikasi sumber masalah (diagnose causes). Peristiwa pelecehan seksual tersebut dilihat disebabkan oleh apa? Apa yang dianggap sebagai penyebab dari pelecehan seksual? Siapa (aktor) yang 
Tabel 3 Pendefinisian Masalah dalam Isi Pemberitaan Kasus Kekerasan Seksual di Kompas.com periode April - Oktober 2020

\begin{tabular}{|c|c|c|}
\hline Tanggal & Judul & $\begin{array}{l}\text { Pendefinisian Masalah dalam Isi Pemberitaan (Define } \\
\text { Problems) }\end{array}$ \\
\hline 9-Okt-20 & $\begin{array}{l}\text { Anggota DPRD } \\
\text { Bojonegoro Jadi } \\
\text { Tersangka KDRT, } \\
\text { Awalnya Berebut Mobil } \\
\text { dengan Istr }\end{array}$ & $\begin{array}{l}\text { Penetapan anggota DPRD Bojonegoro dalam kasus } \\
\text { KDRT terhadap istrinya akibat rebutan ponsel dan mobil. } \\
\text { Visualisasi berita ilustrasi borgol. }\end{array}$ \\
\hline 5-Okt-20 & $\begin{array}{l}\text { Ini } 5 \text { Catatan Solidaritas } \\
\text { Perempuan Tolak } \\
\text { Omnibus Law Cipta } \\
\text { Kerja }\end{array}$ & $\begin{array}{l}\text { Terpinggirkannya hak dan peran perempuan terkait } \\
\text { KLHS, AMDAL, kepemilikan tanah, kedaulatan pangan, } \\
\text { peniadaan cuti keguguran/haid, dan sulitnya lapangan } \\
\text { pekerjaan dalam Omnibus Law. Visualisasi berita } \\
\text { beberapa orang mengenakan hazmat. }\end{array}$ \\
\hline 22-Juli-20 & $\begin{array}{l}\text { Saat Pandemi Ada } \\
700 \text { Kasus Kekerasan } \\
\text { Terhadap Anak dan } \\
\text { Perempuan di Jatim, } \\
\text { Terbanyak Pelecehan } \\
\text { Seksual }\end{array}$ & $\begin{array}{l}\text { Kasus kekerasan terhadap anak di Jatim selama } \\
\text { COVID-19 meningkat tajam khususnya kasus kekerasan } \\
\text { seksual. Visualisasi berita ilustrasi mulut orang yang } \\
\text { dibungkan tangan orang lain. }\end{array}$ \\
\hline 26-Juli-20 & $\begin{array}{l}35 \text { Kasus Kekerasan } \\
\text { Terhadap Anak Terjadi } \\
\text { di Banten, } 95 \text { Persen } \\
\text { Kasus Kejahatan } \\
\text { Seksual }\end{array}$ & $\begin{array}{l}\text { Kasus kekerasan terhadap anak di Banten periode } \\
\text { Januari-Juli 2020, mayoritas kasus kekerasan seksual. } \\
\text { Visualisasi berita ilustrasi kepalan tangan laki-laki dan } \\
\text { sosok anak. }\end{array}$ \\
\hline 27-Juli-20 & $\begin{array}{l}\text { Meski Pandemi, } \\
\text { Perempuan Korban } \\
\text { Kekerasan Bisa } \\
\text { Melapor dari Rumah }\end{array}$ & $\begin{array}{l}\text { Layanan pengaduan kasus kekerasan kepada Komnas } \\
\text { Perempuan melalui Cloud Contact Centre Telkomtestra. } \\
\text { Visualisasi berita ilustrasi bola mata. }\end{array}$ \\
\hline 21-Juli-20 & $\begin{array}{l}\text { Angka Kekerasan } \\
\text { Terhadap Perempuan } \\
\text { dan Anak di Jatim } \\
\text { Meningkat Saat } \\
\text { Pandemi COVID-19 }\end{array}$ & $\begin{array}{l}\text { Data DP3AK menyatakan peningkatan kasus kekerasan } \\
\text { terhadap perempuan dan anak di Jatim akibat PSBB. } \\
\text { Visualisasi berita gambar anak perempuan menutup mata } \\
\text { dan wajahnya. }\end{array}$ \\
\hline 3-Juni 20 & $\begin{array}{l}\text { Komnas Perempuan: } \\
\text { KDRT Meningkat } \\
\text { Selama Pandemi } \\
\text { COVID-19, Mayoritas } \\
\text { Korban Bungkam }\end{array}$ & $\begin{array}{l}\text { Hasil survei Komnas Perempuan kepada } 2.285 \\
\text { responden perempuan dan laki-laki selama April-Mei } \\
2020 \text { mengungkap kekerasan psikologis dan ekonomi } \\
\text { mendominasi kasus KDRT. Visualisasi berita gambar } \\
\text { perempuan posisi telungkup. }\end{array}$ \\
\hline 29-Juni 20 & $\begin{array}{l}\text { Kekerasan terhadap } \\
\text { Perempuan dan Anak di } \\
\text { Karawang Meningkat }\end{array}$ & $\begin{array}{l}\text { Data DP3A Karawang mengungkapkan peningkatan } \\
\text { jumlah kasus kekerasan terhadap perempuan dan anak } \\
\text { tahun } 2018 \text { - 2020. Visualisasi berita gambar mulut } \\
\text { perempuan yang dibungkam. }\end{array}$ \\
\hline 01-Juli-20 & $\begin{array}{l}\text { RUU PKS Ditunda } \\
\text { Lagi, Komnas } \\
\text { Perempuan: DPR Tak } \\
\text { Ada Perhatian Sama } \\
\text { Sekali terhadap Korbar }\end{array}$ & $\begin{array}{l}\text { Penundaan pembahasan RUU PKS akan mengakibatkan } \\
\text { terhambatnya proses hukum yang adil bagi korban } \\
\text { kekerasan di Indonesia. Visualisasi berita gambar } \\
\text { beberapa orang demonstrasi. }\end{array}$ \\
\hline
\end{tabular}

Sekali terhadap Korban 
20-Mei-20 Kekerasan terhadap

Perempuan, Peristiwa

yang Terlupakan Saat

Tragedi Mei 1998

04-Mei-20 CCTV di Hotel yang

Jadi Lokasi Kekerasan

terhadap Wanita

di Taman Sari Tak

Berfungsi

29-April-20 Kemen PPPA:

Kekerasan Perempuan

dan Anak di Tengah

Pandemi COVID-19

Masih Terjadi
53 kasus kekerasan terhadap perempuan saat Mei 1998

tidak pernah ditelusuri dan dibahas pimpinan DPR.

Visualisasi berita gambar beberapa mobil yang dibakar.

Kelalaian sebuah hotel di Tamansari yang tidak memperbaiki CCTV mengakibatkan penanganan kasus kekerasan terhadap seorang perempuan menjadi terhambat. Visualisasi berita gambar kepalan tangan laki-laki dihadapan perempuan yang tertunduk. Peluncuran program Sejiwa dari KemenPPA untuk memberikan layanan kesehatan jiwa bagi korban kekerasan terhadap perempuan dan anak. Visualisasi berita gambar Menteri PPA.

Sumber: Hasil Penelitian, 2020

dianggap sebagai penyebab kasus kekerasan seksual?

Berdasarkan data pemberitaan yang dikumpulkan penulis, terdapat perbedaan identifikasi masalah (diagnose causes) pada kedua portal berita daring Okezone.com dan Kompas.com. Pada pemberitaan di laman Okezone.com dapat diketahui bahwa mayoritas kasus kekerasan seksual yang diberitakan adalah yang terkait kasus artis tertentu dan beberapa kegiatan instansi pemerintah. Kasus kekerasan seksual yang terjadi di Indonesia mendapatkan porsi pemberitaan yang minim.

Sudut pemberitaan kasus kekerasan seksual di laman Okezone.com cenderung masih berorientasi kan pada sisi korban dan keluarganya yang menyajikan uraian latar belakang korban dan keluarga. Liputan mengenai pelaku kerap luput menjadi fokus pemberitaan, kalaupun ada maka pemaparan tentang alasan pelaku melakukan kekerasan seksual yang condong membahasakan tindakan pemerkosaan dan pelecehan seksual akibat terdorong hawa nafsu setelah melihat korban mengenakan pakaian terbuka; atau tindakan pembunuhan yang dilakukan pelaku karena malu atas dugaan perilaku mesum korban. Plot pemberitaan tersebut seakanakan menjustifikasikan tindakan perkosaan, pelecehan seksual, dan pembunuhan yang dilakukan pelaku sebagai bentuk tindakan yang diinisiasi korban sehingga bukan merupakan kesalahan pelaku seutuhnya.

Dengan demikian dalam pemberitaan kasus kekerasan seksual pada laman portal berita daring Okezone.com, pelaku kekerasan seksual tidak pernah diidentifikasikan secara utuh dan jelas, alasan peristiwa kekerasan seksual selalu mengambil sudut pandang bahwa pelaku merasa terdorong melakukan tindak kekerasan seksual bukan karena keinginannya sendiri, serta seakan tindak kekerasan seksual yang dilakukan berada di luar kuasa pelaku.

Selanjutnya, pemberitaan pada laman berita daring Kompas.com dapat diketahui bahwa seluruh pemberitaan kekerasan seksual terkait beberapa kasus kekerasan seksual yang sedang terjadi di Indonesia. Jika dibandingkan Okezone.com maka Kompas.com porsi pemberitaan kasus kekerasan seksual telah mendapat sorotan yang lebih baik.

Sudut pemberitaan Kompas.com cenderung menceritakan kejadian perkara kasus kekerasan seksual secara runtut dan detail mulai dari pengungkapan setting tempat kejadian perkara, identitas korban, identitas pelaku, alasan pelaku, serta pernyataan alur kejadian berdasarkan laporan kepolisian.

Lebih lanjut, pemberitaan Kompas.com terkait kasus kekerasan seksual selama pandemi COVID-19 kerap menyajikan beragam laporan tentang situasi dampak PSBB terhadap perempuan, data kasus kekerasan di beberapa wilayah di Indonesia, serta pembahasan kebijakan yang relevan dengan kekerasan. Penyajian data ini dapat memberikan gambaran situasi riil yang dialami perempuan di berbagai kota di Indonesia. 
Berdasarkan identifikasi sumber masalah (define causes) di atas berdasarkan laman portal berita Kompas.com telah berupaya untuk meliput dari dua sudut pandang (both sides of the story) saat memberitakan kasus kekerasan seksual. Walaupun demikian masih terdapat kekurangan dalam hal menceritakan latar belakang korban sehingga tetap saja sorotan utamanya bukan pelaku. Situasi ini semakin meneguhkan bahwa dengan menyodorkan identitas dan latar belakang korban akan menarik pembaca (selling the story).

Terkait dengan moral judgment, hasil penelitian menunjukkan bahwa penilaian atas penyebab masalah kekerasan seksual dalam pemberitaan yang dimuat dalam Kompas.com dan Okezone.com dapat dimasukkan ke dalam beberapa kategori yaitu nilai moral bahwa: kekerasan seksual terjadi di luar kontrol pelaku, patriarki sebagai ideologi yang melegitimasi kekerasan terhadap perempuan, kekerasan terhadap perempuan dapat menimbulkan berbagai dampak bagi korbannya, belum disahkannya Rancangan Undang Undang (RUU) Penghapusan Kekerasan Seksual (PKS) sebagai bentuk ketidakperhatian dan berdampak terhadap perempuan korban kekerasan seksual.

Kekerasan seksual sebagai suatu tindakan yang terjadi di luar kontrol pelaku terdapat pada teks berita berjudul "Pelaku saat Memperkosa Perempuan di Bintaro dalam Kondisi Mabuk" yang dipublikasikan oleh Okezone.com pada 11 Agustus 2020. Berita ini memperlihatkan bahwa faktor ekonomi, minuman keras, dan pakaian korban merupakan penyebab terjadinya tindak kekerasan seksual (Hambali, 2020). Hal-hal yang disoroti di antaranya status pengangguran pelaku kekerasan seksual serta pakaian korban yang minim. Pada pemberitaan ini dapat diamati bahwa media masih memberikan porsi penilaian moral yang cukup besar pada hal-hal yang seolah berada di luar kontrol pelaku alihalih memposisikan pelaku sebagai pihak yang sepenuhnya berperan dalam tindak kejahatan yang dilakukannya. Penilaian atas korban sebagai pihak yang bersalah juga dapat terlihat pada kutipan berita berikut, "Dia pun mengaku, bahwa perbuatannya dilakukan spontan lantaran melihat korban berpakaian minim di dalam rumah." (Hambali, 2020). Selain menekankan pada pakaian yang dikenakan korban, perkosaan juga diposisikan sebagai tindakan spontan, yang berarti di dalamnya tidak terdapat unsur kesengajaan dari pelaku.

Penilaian terhadap kekerasan seksual yang terjadi karena status pekerjaan pelaku, kondisi mabuk dan pakaian korban yang terbuka berpotensi memberikan jarak antara pelaku dan tindakan yang dilakukannya. Dengan demikian, seolah keadaan eksternal dan korbanlah yang sesungguhnya bersalah atau turut bertanggung jawab atas terjadinya peristiwa tersebut. Konstruksi ini melegitimasi victim blaming yang telah lama dikritisi oleh para peneliti dan aktivis perempuan (Gravelin et al., 2019).

Di sisi lain, pemberitaan media terkait kekerasan terhadap perempuan, khususnya kekerasan seksual, juga telah memperlihatkan upaya media untuk mengedukasi masyarakat tentang kesetaraan gender dengan menempatkan patriarki sebagai akar masalah kekerasan. Hal ini terlihat dari pemberitaan yang berjudul "Perempuan Kian "Terperangkap" di Tengah Pembatasan Sosial COVID-19" tertanggal 20 Mei 2020. Berita ini merupakan berita agregasi $\mathrm{BBC}$ Indonesia yang dipublikasikan di Okezone.com. Fokus dari pemberitaan ini yaitu kekerasan dan potensi kekerasan yang dialami oleh perempuan selama pembatasan sosial di masa pandemi COVID-19 (Agregasi BBC Indonesia, 2020). Konstruksi sosial dan budaya atas peran perempuan dan lakilaki yang didasari atas ideologi patriarki yang diwariskan dari generasi ke generasi disebut melanggengkan relasi kuasa antara perempuan dan laki-laki. Dalam hal ini misalnya anak perempuan diberi beban untuk melakukan semua pekerjaan domestik, sementara anak laki-laki dibebaskan dari kewajiban untuk melakukannya. Ketimpangan dalam relasi kuasa antara laki-laki dan perempuan semakin mengemuka dalam masa pandemi karena hal adanya pembatasan sosial yang mengharuskan masyarakat tetap tinggal di rumah. Hal ini dapat diamati pada kutipan berita berikut,

"Beban domestik yang berlapis, ditambah relasi kuasa yang timpang antara lakilaki dan perempuan dan tekanan ekonomi selama pandemi, menyebabkan kekerasan terhadap perempuan berpotensi kian menjadi, ujar Komisioner Komnas Perempuan Siti Aminah Tardi." (Agregasi BBC Indonesia, 2020).

Meskipun masih memberikan penekanan terhadap kondisi eksternal (tekanan ekonomi) 
sebagai penyebab kekerasan, tetapi kutipan yang dipilih oleh media setidaknya telah menunjukkan bahwa relasi kuasa yang timpang juga menyebabkan kekerasan dapat terjadi. Penilaian moral yang diberikan oleh media terhadap budaya patriarki dan relasi kuasa yang membatasi perempuan ini sejalan dengan hasil penelitian yang memperlihatkan peran media untuk mengedukasi khalayak dan mengkritisi nilai-nilai tradisional gender yang cenderung diskriminatif, khususnya pada perempuan (Maryani \& Adiprasetio, 2017).

Penilaian moral lainnya yang juga dapat ditelaah yaitu terkait dengan berbagai dampak yang dialami perempuan korban kekerasan, termasuk kekerasan seksual. Contohnya pada pemberitaan berjudul "Kekerasan terhadap Perempuan \& Anak Meningkat Selama Wabah Corona" yang dipublikasikan oleh Okezone. com dan "Kemen PPPA: Kekerasan Perempuan dan Anak di Tengah Pandemi COVID-19 Masih Terjadi" yang dimuat di Kompas.com. Kedua berita ini menyoroti peningkatan jumlah kekerasan terhadap perempuan dan anak secara umum dan kekerasan seksual. Selain itu, keduanya juga menarasikan dampak serius dari kekerasan seksual yang mencakup aspek kesehatan, sosial, dan ekonomi (Purnamasari, 2020; Rizky, 2020). Pembingkaian media atas dampak fisik dan psikologis dari kekerasan seksual tersebut menunjukkan adanya urgensi atas penanganan dan antisipasi tindak kekerasan terhadap perempuan.

Poin terakhir dari penilaian moral yang dibingkai oleh media dan menjadi temuan penelitian ini yaitu terkait RUU Penghapusan Kekerasan Seksual (RUU PKS) yang belum kunjung disahkan oleh Dewan Perwakilan Rakyat (DPR). Isu ini mengemuka dalam berita berjudul "RUU PKS Ditunda Lagi, Komnas Perempuan: DPR TakAda Perhatian Sama Sekali terhadap Korban" yang dimuat di Kompas. com. Penundaan ini dinilai sebagai wujud tidak adanya perhatian terhadap kasus kekerasan seksual (Farisa, 2020). Dampak penundaan RUU PKS adalah potensi peningkatan jumlah korban kekerasan seksual dan terhambatnya penanganan serta pemulihan korban kekerasan seksual.

Penilaian moral atas kasus kekerasan seksual yang dimuat di Okezone.com dan Kompas.com terkait erat dengan narasi-narasi yang membangun treatment recommendation atau penyelesaian yang ditawarkan untuk menyelesaikan masalah kekerasan seksual, atau kekerasan terhadap perempuan secara umum. Rekomendasi penyelesaian masalah tersebut di antaranya mencakup: pemberian hukuman terhadap pelaku kekerasan seksual, pendampingan Kementerian Pemberdayaan Perempuan dan Perlindungan Anak (Kemen PPPA) terhadap perempuan korban kekerasan di masa COVID-19, perlunya layanan psikologi nasional untuk masyarakat, perlunya pengesahan RUU PKS.

Rekomendasi solusi yang dibingkai oleh media memperlihatkan bahwa masih terdapat penyelesaian masalah berpusat pada korban sebagai pihak yang mengalami kekerasan, bukan pada antisipasi atau rekomendasi hukuman bagi pelaku. Walaupun telah terdapat rekomendasi untuk mengesahkan RUU PKS sebagai salah satu solusi, namun temuan ini memperlihatkan bahwa framing media atas penyelesaian isu kekerasan masih belum sepenuhnya fokus pada akar masalah kekerasan terhadap perempuan, yakni budaya patriarki dan penegakan hukum bagi pelaku kekerasan.

\section{SIMPULAN}

Berdasarkan pemaparan hasil penelitian dan analisis yang dilakukan penulis, maka dapat disimpulkan bahwa dalam pengidentifikasian masalah peristiwa dan isu kekerasan seksual diberitakan secara berbeda antara Kompas.com dan Okezone.com. Identifikasi sumber masalah pada laman portal berita Kompas.com telah berupaya untuk meliput dari dua sudut pandang (both sides of the story) dibandingkan Okezone. com, walau fokus berita masih menampilkan latar belakang korban.

Penilaian atas penyebab masalah kekerasan seksual dalam pemberitaan yang dimuat dalam Kompas.com dan Okezone.com, dapat dimasukkan ke dalam beberapa kategori nilai moral yakni: kekerasan seksual terjadi di luar kontrol pelaku, patriarki sebagai ideologi yang melegitimasi kekerasan terhadap perempuan, kekerasan terhadap perempuan dapat menimbulkan berbagai dampak bagi korbannya, serta belum disahkannya Rancangan Undang Undang (RUU) Penghapusan Kekerasan Seksual (PKS) sebagai bentuk ketidakperhatian dapat berdampak kepada perempuan korban 
kekerasan seksual. Rekomendasi solusi yang dibingkai oleh media memperlihatkan bahwa masih terdapat penyelesaian masalah terpusatkan pada korban sebagai pihak yang mengalami kekerasan, bukan pada antisipasi atau rekomendasi hukuman bagi pelaku.

Dengan demikian, narasi kasus kekerasan seksual dalam pemberitaan laman portal daring dua media besar yakni Kompas.com dan Okezone.com selama periode PSBB tetap memperteguh budaya patriarki, cenderung meletakkan kesalahan pada korban kekerasan seksual (victim blaming), masih belum memberikan porsi berita secara optimal, serta belum adanya narasi penegakan hukum yang adil dan berimbang bagi penanganan kasus kekerasan seksualdi Indonesia. Untukitu penulis menyarankan perlu dikembangkan kajian yang mengambil fokus komunikasi publik dalam mengedukasi isu kekerasan seksual sebagai upaya nyata dan aktif para akademisi dalam memberikan rekomendasi ilmiah dan pragmatis bagi masyarakat serta merupakan dorongan agar pemberitaan kasus kekerasan seksual lebih berimbang dan mengedepankan posisi korban sebagai subjek.

\section{DAFTAR PUSTAKA}

Agregasi BBC Indonesia. (2020). Perempuan kian "terperangkap" di tengah pembatasan sosial covid-19. Okezone. Com. https://nasional.okezone.com/ $\mathrm{read} / 2020 / 05 / 20 / 337 / 2217082 /$ perempuankian-terperangkap-di-tengah-pembatasansosial-covid-19

Anggoro, A. D. (2014). Media, politik dan kekuasaan. Jurnal Aristo, 2(2), 25-52.

Borah, P. (2011). Conceptual issues in framing theory: a systematic examination of a decade's literature. Journal of Communication, 61(2), 246-263. https:// doi.org/https://doi.org/10.1111/j.14602466.2011.01539.x

Couldry, N., \& Hepp, A. (2016). The mediated construction of reality: society, culture, mediatization. Jakarta: Polity Press.

Ekweonu, C. L. (2020). Newspaper coverage of domestic violence against women during covid-19 lockdown. Nnamdi Azikiwe University Journal of Communication and Media Studies, 1(2), 1-14.
Entman, R. (2015). Mass media, representations in (J. D. B. T.-I. E. of the S. \& B. S. (Second E. Wright (ed.); pp. 738-742). Elsevier. https://doi.org/https://doi.org/10.1016/ B978-0-08-097086-8.95043-8

Entman, R. M. (1993). Framing: toward clarification of a fractured paradigm. Journal of Communication, 43(4), 51-58. $\quad$ https://doi.org/https://doi. org/10.1111/j.1460-2466.1993.tb01304.x

Geertsema \& Sligh, M. (2018). Gender issues in news coverage. The International Encyclopedia of Journalism Studies, 1-8. https://doi.org/10.1002/9781118841570. iejs0162

Gravelin, C. R., Biernat, M., \& Bucher, C. E. (2019). Blaming the victim of acquaintance rape: individual, situational, and sociocultural factors. In Frontiers in Psychology (Vol. 9, p. 2422). https:// www.frontiersin.org/article/10.3389/ fpsyg.2018.02422

Hackett, R. A. (1984). Decline of a paradigm? bias and objectivity in news media studies. Critical Studies in Mass Communication, 1(3), 229-259. https:// doi.org/10.1080/15295038409360036

Hambali. (2020). Pelaku saat memperkosa perempuan di Bintaro dalam kondisi mabuk. Okezone.Com. https://megapolitan.okezone.com/ $\mathrm{read} / 2020 / 08 / 11 / 338 / 2260106 /$ pelakusaat-memperkosa-perempuan-di-bintarodalam-kondisi-mabuk

Ihsanudin. (2020). Ada 7 bantuan pemerintah selama pandemi covid-19, Berikut Rinciannya... Kompas. Com. https://nasional.kompas.com/ $\mathrm{read} / 2020 / 08 / 26 / 09222471 /$ ada-7-bantuanpemerintah-selama-pandemi-covid-19berikut-rinciannya?page $=$ all

Johnston, A., Friedman, B., \& Sobel, M. (2015). Framing an emerging issue: how u.s. print and broadcast news media covered sex trafficking, 2008-2012. Journal of Human Trafficking, 1(3), 235-254. https://doi.org/ 10.1080/23322705.2014.993876

Kamila, R. A., \& Laksmi, L. (2018). Informasi mengenai perempuan dalam berita di kompas.com female. Jurnal Ilmu Informasi, Perpustakaan, Dan Kearsipan, 19(2), 97-107. https://doi.org/10.7454/ 
jipk.v19i2.126

Kemen PPA. (2020). Angka kekerasan terhadap anak tinggi di masa pandemi, kemen PPPA sosialisasikan protokol perlindungan anak. Kemenppa.Go.Id.https://www.kemenpppa. go.id/index.php/page/read/29/2738/angkakekerasan-terhadap-anak-tinggi-di-masapandemi-kemen-pppa-sosialisasikanprotokol-perlindungan-anak

Kofman, Y. B., \& Garfin, D. R. (2020). Home is not always a haven: the domestic violence crisis amid the covid-19 pandemic. Psychological Trauma: Theory, Research, Practice, and Policy, 12, 1998-2000. https://doi.org/10.1037/tra0000866

Kurnia, D., \& Assidiq, Y. (2018). Jumlah pembaca berita media daring terus meningkat. Republika.Co.Id. https:// nasional.republika.co.id/berita/p83old399/ jumlah-pembaca-berita-media-daringterus-meningkat

Linström, M., \& Marais, W. (2012). Qualitative news frame analysis: a methodology. 2137.

Maryani, E., \& Adiprasetio, J. (2017). Magdalene.co sebagai media advokasi perempuan. Jurnal Ilmu Komunikasi, 14(1), 111. https://doi.org/10.24002/jik. v14i1.836

Morrison, M. A., Parker, K. M., Sadika, B., Sameen, D.-E., \& Morrison, T. G. (2021). 'Newsworthy enough?': media framing of canadian LGBTQ persons' sexual violence experiences. Psychology \& Sexuality, 12(1-2), 96-114. https://doi.org/10.1080/1 9419899.2020.1729845

Pada, P., Akbar, D. D., \& Abidin, S. (2020). Analisis wacana sara mills pemberitaan blaming victim perempuan korban perkosaan pada okezone.com. Scientia Journal.

Pawito, P. (2014). Meneliti ideologi media: catatan singkat. Profetik, 7(1), 5-14.

Pennington, R., \& Birthisel, J. (2015). When new media make news framing technology and sexual assault in the Steubenville rape case. https://doi. org/10.1177/1461444815612407

Potter, W. J. (2016). Media literacy (Eighth Edi). SAGE Publications.

Powell, K. A. (2011). Framing islam: an analysis of u.s. media coverage of terrorism since 9/11. Communication Studies, 62(1), 90-112. https://doi.org/10.1080/10510974. 2011.533599

Purnamasari, D. M. (2020). Kemen PPPA: kekerasan perempuan dan anak $d i$ tengah pandemi covid-19 masih terjadi. Kompas.Com. https://nasional.kompas. $\mathrm{com} / \mathrm{read} / 2020 / 04 / 29 / 16440841 /$ kemenpppa-kekerasan-perempuan-dan-anak-ditengah-pandemi-covid-19-masih

Radhakrishnan, V., Sen, S., \& Singaravelu, N. (2020). Data: domestic violence complaints at a 10-year high during COVID-19 lockdown. The Hindu. https://www.thehindu.com/data/datadomestic-violence-complaints-at-a-10year-high-during-covid-19-lockdown/ article31885001.ece

Rahayu, M., \& Agustin, H. (2019). Representasi kekerasan seksual terhadap perempuan di situs berita tirto.id. Jurnal Kajian Jurnalisme, 2(1), 115-134. https://doi. org/10.24198/kj.v2i1.21321

Rizky,F.(2020).Kekerasanterhadapperempuan \& anak meningkat selama wabah corona. Okezone.Com. https://nasional.okezone. $\mathrm{com} / \mathrm{read} / 2020 / 04 / 29 / 337 / 2206679 /$ kekerasan-terhadap-perempuan-anakmeningkat-selama-wabah-corona

Rotenberg, C., \& Cotter, A. (2018). Policereported sexual assaults in canada before and after \# MeToo, 2016 and 2017. In Juristat (Issue 85). https://www150.statcan.gc.ca/ n1/en/catalogue/85-002-X201800154979

Rumata, V. M. (2017). Digitalisasi dan eksistensi media cetak (studi kualitatif majalah go girl dan harian suara pembaharuan). Komunikologi, 15(2), 128-136.

Shaw, R. L., \& Giles, D. C. (2009). Motherhood on ice? a media framing analysis of older mothers in the uk news. Psychology \& Health, 24(2), 221-236. https://doi. org/10.1080/08870440701601625

Shoemaker, P. J., \& Reese, S. D. (2013). Mediating the message in the 21st century: a media sociology perspective (Third Edit). Routledge. https://doi. org/10.4324/9780203930434

Sulistiyono, S. T. (2020). Komnas perempuan sebut selama 9 tahun ada 46 ribu lebih kasus kekerasan seksual. Tribunnews. Com. https://www.tribunnews.com/ 
nasional/2020/07/23/komnas-perempuansebut-selama-9-tahun-ada-46-ribu-lebihkasus-kekerasan-seksual

Susilo, D., \& Haezer, E. (2017). Konstruksi seksualitas perempuan dalam berita pemerkosaan di teks media daring. Jurnal Kawistara, 7(1), 41. https://doi. org/10.22146/kawistara.15636

UN Women. (2020). Covid-19 and violence against women and girls: addressing the shadow pandemic (Issue 17). https://www.unwomen.org/-/media/ headquarters/attachments/sections/library/ publications/2020/policy-brief-covid-19and-violence-against-women-and-girls-en . pdf? $1 \mathrm{a}=\mathrm{en} \& \mathrm{vs}=640$

Yan, F. (2020). Image, reality and media construction: a frame analysis of german media representations of China. Springer Singapore.

Zuhra, W. U. N. (2017). Pertumbuhan oplah koran: melambat, melambat, menurun. Tirto.Id. https://tirto.id/pertumbuhanoplah-koran-melambat-melambatmenurun-ciy 7 